\title{
Improving Iranian High School Students' Reading Comprehension Using the Tenets of Genre Analysis
}

\author{
Rezvan Adelnia \\ English Department, Faculty of Humanities, Najafabad Branch, Islamic Azad University, Najafabad, Isfahan, Iran \\ E-mail: adelnia_re@yahoo.com \\ Hadi Salehi (Corresponding author) \\ English Department, Faculty of Humanities, Najafabad Branch, Islamic Azad University, Najafabad, Isfahan, Iran \\ E-mail: hadisalehi1358@yahoo.com
}

Doi:10.7575/aiac.alls.v.7n.4p.187

URL: http://dx.doi.org/10.7575/aiac.alls.v.7n.4p.187
Received: 03/04/2016

Accepted: 24/06/2016

\begin{abstract}
This study is an attempt to investigate impact of using a technique, namely, genre-based approach on improving reading ability on Iranian EFL learners' achievement. Therefore, an attempt was made to compare genre-based approach to teaching reading with traditional approaches. For achieving this purpose, by administering the Oxford Quick Placement Test (OQPT) 80 female EFL learners were chosen. We assigned the participants to an experimental and a control group randomly. A reading test was administered on the whole population as the pretest. 10 reading passages were taught using the tenets of genre based instruction, while the same reading passages were taught to the participants in the control group traditionally. After 10 sessions of instruction when all the passages were taught, the participants sat for a posttest. The research hypothesis according to which using genre-based approach to teaching reading does not significantly improve reading ability of Iranian EFL learners was rejected at 0.05 level of significance. Differently stated, using genre-based approach to teach reading can improve EFL learners' performance in their reading classes. The result also showed that there is a meaningful difference between the performance of students who go under a traditional approach in teaching reading comprehension and those who are instructed using genre-based approach. The outcomes of this study can be used by English language teachers to consider the importance of a genre-based instruction.
\end{abstract}

Keywords: Genre-Based Instruction (GBI), Reading comprehension, Iranian EFL learners, Reading comprehension

\section{Introduction}

Instructing reading skills to the students is one of the most important purposes of any language course. Reading comprehension is one of the crucial skills fundamental for any language learner including the high school students. Accordingly, the students need to make their reading comprehension better to further their studies in higher education or many projects that the teachers ask them. So far, a number of methodologies have been introduced in teaching English language in general and reading comprehension in particular. Among various approaches in teaching reading comprehension (e.g. critical reading, critical discourse analysis, skill model, etc.) genre analysis seems to be prominent. Review of literature shows that implementing a genre-based instruction in teaching reading skill influences the reading abilities of the students positively (e.g. Shishehsaz, 2006).

Genre analysis refers to "a class of communicative events, the members of which share some set of communicative purposes. These purposes are recognized by the expert members of the parent discourse community, and thereby constitute the rationale for the genre" (Swales, 1990. P. 58). In other words, genre means "the regularities of staged, goal oriented social processes" (Martin, 1993) in which "the typification of social and rhetorical action" (Miller, 1984, p. 159) were recognized. In fact, the main purposes of genre are given to the "shared purpose rather than on similarities of form or some other criteria" (Swales, 1990, p.46). Bhatia (1993) argued that the quintessence of a genre "is primarily characterized by the communicative purpose(s) that it is intended to fulfill' (p. 13). He emphasized that

(The) communicative purpose(s) determine the structure of the genre; should the purpose(s) change in a significant way, the genre would be different. Bhatia continues his elaboration with the observation that 'communicative purpose is a fairly reliable criterion to identify and distinguish sub-genres' (Bhatia, 1993, p. 14).

Genre-based approach, also called genre-based instruction (GBI), is a current trend to teaching language skills including reading (Wennerstrom, 2003). According to Osman (2004) teaching specific genres commonly required by the students in the academic situations, the overt teaching of the language patterns and social conventions of these genres, which makes the students more aware about these genres' structures and subsequently enhance their language skill are some distinct characteristics of GBI. Some studies have been conducted that prove the efficacy of GBI. Swami's study (2008) 
which evaluated the effectiveness of GBI is one of the studies in this area. He found out that exposing learners to this approach result in their knowledge acquisition and genres' convention awareness which consequently help enhance their confidence and cause them to have a positive attitude towards learning language. It seems that genre familiarity and reading comprehension have a close relationship. Hence, this study utilized an innovative model for the improvement of Iranian high school students' reading comprehension in English.

Iranian EFL learners, specifically at high school level, mostly have problem in dealing with reading passages. So it is the teacher art to provide good support and to choose the best way to teach reading. One of the major problems is that the EFL teachers usually fail to apply an appropriate method to teach reading. Despite the demand for proficient EFL readers it seems that the outcome of the Iranian high school graduates is not sufficient in terms of reading ability and except some top students the rest of the graduate students are not proficient enough in dealing with texts.

Many facets of students' academic performance can be positively influenced by improved reading comprehension skills. Students who can read and understand reading assignments effectively are more ready for class. Consequently their class participation is improved and their note taking is more accurate and complete. As students become more proficient and effective in reading, their reading performance on exams and quizzes can be improved greatly. Understanding reading assignments better fosters Students' interest and motivation in a subject. Moreover, gaining reading proficiency enhances the students' self-esteem.

\subsection{Statement of the Problem}

One of the major problems is that the EFL teachers usually fail to apply an appropriate method to teach reading. Despite the demand for proficient EFL readers it seems that the outcome of the Iranian high school graduates is not sufficient in terms of reading ability and except some top students the rest of the graduate students are not proficient enough in dealing with texts. Students who can read and understand reading assignments effectively are more ready for class. Consequently their class participation is improved and their note taking is more accurate and complete. Understanding reading assignments better fosters Students' interest and motivation in a subject. Moreover gaining reading proficiency enhance the students' self-esteem.

Challenges and difficulties the students experience in reading comprehension is one of the concerns which is focused on by many. In effect, in Iranian high schools reading skill is regarded as one of the crucial skills to be instructed in teaching English language programs. It denotes that teaching reading comprehension through the tenets of genre analysis may make the reading comprehension of the Iranian high school students better. Therefore, the present study was administered to fill the gap in the literature by reporting on a study which compares genre analysis approach to teaching reading to Iranian high school students with traditional approaches to teaching reading.

\subsection{Research Questions and Hypotheses}

The present research is going to answer the following research questions:

Does using genre-based approach to teaching reading significantly improve reading ability of Iranian EFL learners?

Is there any significant difference between the performances of students who will go under a traditional approach in teaching reading comprehension and those who will be instructed using genre-based approach?

Formulated null hypotheses of the mentioned research questions are as follows:

H01: Using genre-based approach to teaching reading does not significantly improve reading Iranian EFL learners' ability.

H02: There is no significant difference between the performances of students who will go under a traditional approach in teaching reading comprehension and those who will be instructed using genre-based approach.

\subsection{Significance of the Study}

Many Iranian high school students experience difficulties with the reading. Due to the fact that being proficient in reading is a must for language learners, the findings of this present paper may help the TEFL teachers. The findings of this study may recommend that during the reading courses in high schools, teachers implement the bases of genre-based instruction.

Different approaches to teaching reading, as mentioned above, can positively or negatively influence the EFL learners' performance on reading classes. That is to say, through implementing appropriate teaching methods, students can make sense of what they read more easily. Therefore, reading methodology constitute an important component of second/foreign language learning. So the results of the study will be important for SLA researchers who are interested in developing reading books for second/foreign language learners.

The results of the study will, therefore, be helpful for teachers, so as to enable language teachers to decide whether implementing genre-based approaches to teaching reading should be given more or focal attention in reading comprehension classes. The present research provides practical recommendation for practitioners to increase readers' awareness and use different approaches to teaching reading. The results can encourage language teachers to take a more systematic approach in teaching reading and planning their programs in classrooms. 


\section{Review of the Literature}

\subsection{Genre-Based Approach}

The term "genre" is used in different contexts to refer to the convention of certain texts in certain cultures (Hammond \& Derewianka, 2001). According to Swales (1990), genre can be considered as "a class of communicative events, the members of which share some set of communicative purposes." Genre-oriented approach started in the late 1980s. It was first employed in the ESP context, which marked the "infancy" of the genre movement (Swales, 2008). However, genre and its application in language pedagogy became popular in the 1990s. Genre-based instruction is a "fresh," new and improved instruction in teaching language skills, an approach that helps language learners in the tertiary level to master the English language (Osman, 2004).

Genre analysis is among the concepts which has been considered in the field of education. Genre analysis has been particularly utilized in the foreign language teaching to improve the reading comprehension of the students. By genre approach the students are provided with explicit knowledge about language. The applied methodology of this genre is based on Vygotsky's (1934/1978) and the American educational psychologist Bruner's work (1986).

According to Hyland (2007), because of the attention paid to language, content, and contexts, language learners are provided with very real benefits by genre based instruction (GBI). GBI has some features which bring some advantages to the EAP/ESP classroom: explicit (clarifying what to learn to support writing skills' acquisition); systematic (offering a logical frame to focus on both language and contexts); needs-based (ensuring that course objectives and contents are assigned based on students' need analysis); supportive (assigns a vital function to language teachers in scaffolding students' learning and creativity); empowering (providing access to valued discourse various patterns and possibilities ); critical (providing learners with resources so that they comprehend and challenge valued texts); and consciousnessraising (raising teachers' understanding/knowledge toward the texts to help learners in their writing efficiently). Genrebased teaching provides learners with an explicit understanding of the ways in which target genres' texts are structured and the reasons why they are written in special formats, this feature of genre-based instruction is concerned with the present study, since it focuses on understanding the text. It is really helpful for preparing L2 students to adapt themselves successfully to any academic setting in different majors (Park, 2006).

\subsection{Genre Approach Different Theories}

Flowerdew and Swales (as cited in Hyon, 1996), at first, emphasized on the genre approach by focusing on genres' formal distinction to help students understand texts' communicative objectives and linguistic characteristics and ignoring content and their social environments' specific roles(p. 695). Genres were regarded devices for examining and teaching written texts by these experts. Devices that were needed by the students to master in specific settings like English for academic purposes and English for professional communication classrooms.

According to Hyon, a genre is a "systemic functional linguistics that is concerned with the relationship between language and its functions in social settings" (Hyon, 1996, p. 696); we can analyze a text by focusing on language special features. Any special genre shows a specific kind of text. Gustafsson (1975, as cited in f, 1993) analyzed legislative genre's syntactic aspects and presented some statistics about using different clauses: $10 \%$ of all clauses are that clauses, $31 \%$ adverbial clauses, $11 \%$ comparative clauses, and $47 \%$ relative clauses (p. 25). His findings showed that more subordinating devices, e.g., relative or adverbial clauses are used in legislative documents compared to any other genre. Furthermore, Hyon (1996), quoting Halliday (1978), claimed that a certain genre's linguistic features were key features that reflect the broader social situations (p. 697).

Researches on the genres' style focus on social contexts which produce genres and on their ethnographic description while ESP genre studies mostly are concerned with linguistic methods of analyzing genres (Hyon, 1996, p. 696). Medway (1994, as cited in Byram, 2004) believed that genre should be viewed within "the complex social, cultural, institutional disciplinary factors at play in the production of specific pieces of writing" (p. 235). This means that not only the form of communication but also the social action used to accomplish it should be the focus of genre approach attention (Miller, 1984, p. 153).

\subsection{Empirical Background}

Most of the studies conducted on genre-based instruction so far, are concerned with the role and usage of genre-based approach on writing. In the following section a glance is taken to the existing literature on genre-based instruction and reading along with other skills. Haria and Midgette (2014) made an investigation to examine genre-based instruction effect on the students' reading comprehension strategy. Therefore, as the subjects of the study seven students were selected from among fifth-grade students who had reading difficulties. Identifying, summarizing, and analyzing the argumentative texts instructed to them. The results of their study revealed improvement on the students' proficiency in identifying the argumentative elements and summarizing arguments.

Rozimela (2014) investigated the relationship between genre awareness and reading comprehension of EFL students. Thirty four students were the subjects of his study. The subjects were asked to recognize the genres of 10 different texts from five diverse genres as well as to answer a 60-item test which examined their knowledge about genres and an 80item test on reading comprehension of the exposed texts. His study illustrated that there is a meaningful relationship between genre awareness and reading comprehension of EFL students. Furthermore, the results of his study showed that the students with higher genre awareness significantly outperformed on reading comprehension. 
The effects of genre-based instruction on ESP learners' reading comprehension was investigated by Sadeghi, TaghiHassani and Hemmati (2013). 116 junior and senior B.S students (both males and females) of Islamic Azad University of Kurdistan, studying biology were the participants of the study. They were randomly assigned into control and experimental groups. The experimental group were taught (genre-group) based on the genre and the control group (non-genre-group) based on the traditional method of teaching ESP, which is usually used in Iranian universities. One 30-item proficiency test and two 30-item standard tests of English reading comprehension were administered. A t-test was used to analyze the scores of the reading comprehension tests. Independent samples test showed that genre-based teaching enhance ESP learners' reading comprehension ability significantly. Descriptive and inferential statistics also revealed that learners' reading comprehension improved significantly compared to non-genre-group.

Shabani Minaabad and Fallahe Khoshkholgh (2012) examined the effect of genre-based pedagogy on the reading comprehension of English for specific purpose leaners and the relationship between their reading comprehension achievement and their general English proficiency. To investigate the corresponding hypotheses, 150 computer engineering BA students attending English for specific purpose classes were selected. Those subjects who scored between 50-100 on the Michigan test (standard GEP test) were assigned to high proficiency level and those scored between 0-50 were placed in low proficiency level. Then each level in turn was randomly divided into an experimental and a control group. The instructional procedures lasted six sessions before the posttest was administered. Because of the specific nature of the research questions, a factorial design seemed appropriate. The results were analyzed by a twoway ANOVA. The results show that genre-based pedagogy affects the reading comprehension of the English for specific purpose learners significantly. The results also reveals that there is a relationship between English for specific purpose learners' reading comprehension achievement and their general English proficiency.

Khatibi (2014) studied genre-based tasks' effects on EFL learners' speaking performance and discussed whether genrebased tasks improves EFL learners' performance on speaking tests. He also explored age factor effect on speaking ability of EFL learners in genre based tasks, i.e. teenagers (13-16 years old) and young adults (24-27 years old). For this, some generic based consciousness-raising tasks (CRT) were taken from Benedict (2006) proposed model for developing control over a genre-based treatment procedures. Two different speaking tests with different genres (e.g. recount, report, review, etc.) were used as pretest and posttest. They were given to 120 senior university students studying English language translation. Findings showed that consciousness-raising tasks influence EFL learners' speaking performance significantly. Though, generic-based CRTs influence did not differ across different ages. Generally, the results provided empirical evidence for the facilitative effect of generic-based consciousness-raising tasks on speaking performance of EFL learners.

The effectiveness of genre-based approach to teaching writing through the use of model texts was investigated by Swami (2008). He was going to identify adjustment letter's moves, the allowable moves order and the strategies which were used to realize the moves. It is essential to view genre as consisting of a series of moves from a language teaching view point (Swales, 1990). He pointed out that a part of a text which achieves a particular purpose within a text is considered a move. Apart from moves' analysis, this study also look at the content, structure and language of learners' writing. The genre-based approach application to teaching writing in ESP context was investigated in this study, especially for ESP learners who wanted to use English in the professional setting. In genre-based approach language teaching 'moves' of a genre are taught to the learners to raise the awareness of the linguistic features associated with the moves. It is done as a way to help learners overcome their writing difficulties appropriately and effectively. This study was going to help learners decide on the kind of information they want to include in their writing so that they can create meaningful and purposeful texts.

\section{Methodology}

\subsection{Participants}

From among Iranian high school students studying in Isfahan high schools, 80 females (all girls with no woman) were selected through administering the Oxford Quick Placement Test (OQPT). In fact, the chosen participants had scores by one standard deviation above and below the mean score. The participants were all in grade three and their age ranged between15-17. They were Persian native speakers. To control other factors, they were chosen from the students taught by the same teacher. All participants' field of study was mathematics. They were selected based on their availability. Their general English proficiency level was intended to be at the same level. The subjects were considered homogenous since they were all foreign language learners and none of them experienced living in an English speaking country. All the participants spoke English as their foreign language in their classroom. The subjects were categorized into an experimental and a control group, 40 subjects in each group.

\subsection{Instrumentation}

In order to come up with satisfactory answers to research questions, a corpus consisting of 10 authentic reading comprehension passages which were retrieved from http://www.readworks.org/, the Oxford Quick Placement test (OQPT), a reading test as pre as well as posttest, and a model of genre-based approach were utilized. These instruments are clarified clearly in following sections.

\subsubsection{The Corpus}

In order to find out whether the tenets of genre-based approach can enhance reading comprehension of EFL learners, some reading passages were needed. To this end, a corpus of authentic reading passages were derived from http://www.readworks.org/ based on the general proficiency level of high school students it was tried to choose some 
passages at the same level of the reading passages in high school grade three English book. The corpus consisted of 10 authentic reading passages, the topics of which were non-fiction. As the focus of this study was on the tenet of genre, the genre of all the passages was the same and descriptive.

\subsubsection{Oxford Quick Placement Test (OQPT)}

As shown in Appendix A, the test consists of sixty items with different question formats comprising of two parts (Part one and Part two). There are multiple choice, item matching, and cloze test type items in the test. In each item there is a missing word for which there are four options. Students should find the correct item among these options. All of the 60 out of 100 chosen participants for the present study got a 30-46 score were assigned to intermediate level based on the test scoring level chart and categorized to be at the same level according to the OQPT results. The reason why the researcher of the study decided to utilize OQPT as the students' measure of proficiency was because the test is a standard proficiency test, and its validity and reliability were assumed to be satisfactory.

\subsubsection{Reading Pre and Posttests}

To set the participants' reading comprehension level homogeneity, a reading test was devised based on the 10 reading passages under study. The reading test comprised of different test items, including multiple choice items, cloze test items, true/false items and item matching. The number of items in the test were 60 . The test was given to 15 three-grade high school students who were not among the participants to find the reliability this test. These 15 students had the same characteristics as the subjects. The Cronbach Alpha Coefficient level of the test was calculated to be 0.81; therefore, it was concluded that the test was reliable enough to be employed in this study. Before administering this test, to check the construct validity of the test, it was checked by a panel of experts including 3 TEFL lecturers. In order to prevent the test-wise effect of this test in the post test, the item arrangement was modified in the posttest. Each correct answer received one mark in the scoring process. No penalty or negative score was determined for wrong answers.

\subsection{Procedure}

In the present study a quasi-experimental design was used. As said earlier, the subjects of the study were 80 Iranian grade three high school students. To conduct the study, at first the issue was consulted with the people in charge of high school, and as the researcher is a language teacher, the high school official stuff consented to cooperate. The participants were then randomly placed into an experimental and a control group. At the outset of the study, in order to choose and ensure the homogeneity of these participants in terms of their general language proficiency, the OQPT was run among the student population studying at high schools in Isfahan. It should be said that before administering each phase of the study or running each test, the participants were given enough information about the type and purpose of the tests and materials; they were also given enough explanations on how to complete them. In addition, before administering the study, the participants were asked whether they were willing to take part in the study or not, and they were assured that their information would remain confidential.

As the topic of this study suggests, this research was going to study any possible impact of using genre-based approach on improving reading comprehension of Iranian EFL learners; therefore, in order to make sure of the homogeneity of the participants in terms of their reading comprehension, a reading test was run among them. As it was said above, the reading test was designed based on the reading passages used in the corpus.

As the next step, in order to find the effect of genre based instruction on reading comprehension of high school students, the treatment was conducted. The same reading passages were taught to the participants in the two groups. However, there were some differences in the way the materials were presented.

The treatment for experimental group was as follow: first, the teachers activated students' background knowledge of the main idea of each passage, by clarifying the main idea of the passage and by identifying their different sections they helped students to gain texts' conceptual knowledge. In fact, different aspects of the genre of the exposed materials (collocations, genre types, lexical and grammatical features as well as the similarities and differences among the exposed texts, were discussed in the experimental group).

The instructional procedures of the control group were different. For this group, the usual method of teaching reading in Iranian language classes was used. The mentioned corpus was presented without emphasizing the texts' hierarchical and generic structure. The passages were given in three phases of pre reading, while reading and post reading stages. Each of the passages from the corpus was given to the students without any special background about the previous or following moves. Then the meaning of the words were taught, the necessary structural points were explained and different parts were translated without any attempt to establish coherence between different parts of the passage. Both groups underwent a course of 10 session, one for each passage, during five weeks. In fact, the study was conducted in 12 sessions, with one session for the reading pre-test and one for the reading posttest. After all the passages were taught, the participants sat foe a posttest.

\subsection{Data Analysis}

The reading corpus was taught to the two groups under study using a three-phase model which is usual in different reading-based courses. These phases included pre-reading, during or while-reading and post-reading stages. The two groups received the same instruction with the same credit hours and the same topics. The experimental group; however, was instructed using an innovative model in which the students' attention was directed to different aspects of the genre of the exposed materials (collocations, genre types, lexical and grammatical features as well as the similarities and differences among the exposed texts). However, the control group just received the instruction in three phases without 
being instructed in terms of genres, collocation, or being consciously raised in terms of the linguistic features of the exposed texts.

\section{Results}

\subsection{Results of the Pretest}

At the outset of the study, a reading pretest was given to the participants of the two groups. An independent-samples ttest was administered to the pretest scores of experimental and control groups, the results of which are presented in Tables 1 and 2 .

Table 1. Descriptive Statistics of the Reading Pretest of Experimental and Control Groups

\begin{tabular}{llllll}
\hline & Groups & $\mathrm{N}$ & Mean & Std. Deviation & Std. Error Mean \\
\hline Pretest scores & Exp. & 40 & 52.1250 & 8.12779 & 1.28512 \\
\cline { 2 - 6 } & Ctl. & 40 & 51.2000 & 6.32537 & 1.00013 \\
\hline
\end{tabular}

As the results in Table 1 show, the mean score of the experimental group is 52.12, and that of the control group is 51.20. This shows a mean difference of 0.88 which seems not to be significant. However, to ensure the lack of significance of the mean difference, an independent-samples t-test was run, and the results of which are presented in Table 2.

Table 2. Results of the Independent-samples t-test of the Scores of the Reading Pretest

\begin{tabular}{|c|c|c|c|c|c|c|c|c|c|}
\hline & & \multicolumn{2}{|c|}{$\begin{array}{c}\text { Levene's Test for } \\
\text { Equality of } \\
\text { Variances }\end{array}$} & \multicolumn{6}{|c|}{ t-test for Equality of Means } \\
\hline & & \multirow[t]{2}{*}{$\mathrm{F}$} & \multirow[t]{2}{*}{ Sig. } & \multirow[t]{2}{*}{$\mathrm{t} \quad \mathrm{df}$} & \multirow[t]{2}{*}{$\begin{array}{l}\text { Sig. }(2- \\
\text { tailed) }\end{array}$} & \multirow[t]{2}{*}{$\begin{array}{c}\text { Mean } \\
\text { Difference }\end{array}$} & \multirow[t]{2}{*}{$\begin{array}{l}\text { Std. Error } \\
\text { Difference }\end{array}$} & \multicolumn{2}{|c|}{$\begin{array}{c}95 \% \text { Confidence Interval } \\
\text { of the Difference }\end{array}$} \\
\hline & & & & & & & & Lower & Upper \\
\hline \multirow[t]{2}{*}{$\begin{array}{l}\text { Pretest } \\
\text { scores }\end{array}$} & $\begin{array}{l}\text { Equal } \\
\text { variances } \\
\text { assumed }\end{array}$ & 1.781 & .186 & .56878 & .572 & .92500 & 1.62843 & -2.31695 & 4.16695 \\
\hline & $\begin{array}{l}\text { Equal } \\
\text { variances not } \\
\text { assumed }\end{array}$ & & & .56873 .56 & .572 & .92500 & 1.62843 & -2.32003 & 4.17003 \\
\hline
\end{tabular}

According to the results given in Table 2, the level of significance is 0.572 that is higher than the identified level of significance $(0.572>.05)$. This way it can be concluded that there was no meaningful difference between the performance of experimental and control groups at the beginning of the study.

\subsection{Addressing the First Research Hypothesis}

In order to find evidence for the rejection or acceptance of the first null hypothesis, a paired samples t-test was run between the pre and posttest scores of the experimental group. The results are presented in Tables 3 and 4.

Table 3. Descriptive Statistics of the Reading Pre and Posttest of Experimental Group

\begin{tabular}{llllll}
\hline & & Mean & N & Std. Deviation & Std. Error Mean \\
\hline Pair 1 & Exp. Pre-test & 52.1250 & 40 & 8.12779 & 1.28512 \\
\cline { 2 - 6 } & Exp. Post-test & 67.5000 & 40 & 16.06397 & 2.53994 \\
\hline
\end{tabular}

As it is seen in Table 3, the mean difference of the participants in experimental group in pre and posttest is 15.38 , with the mean score of pretest being 52.12 and that of posttest being 67.50. The difference between the two groups is considered to be statistically significant. Figure 1 shows the differences in pictorial format. 


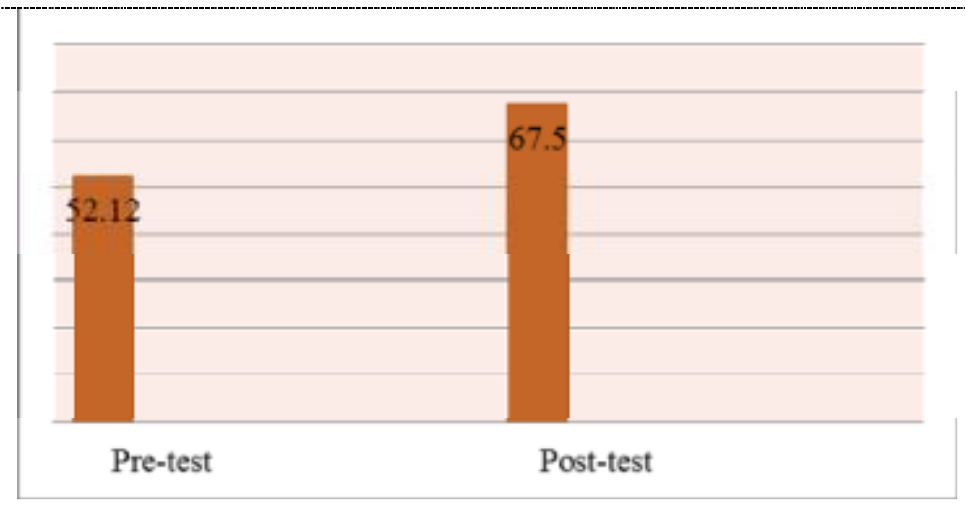

Figure 1. Mean Difference between the Performance of the Experimental Group in Pre and Posttests

The difference of the two groups' performance is crystal clear in Figure 1. The second column, representing the posttest is taller than the first one. However, to be more objective for this claim, a paired-samples t-test was run on the mean scores of the experimental pre and posttest scores. The results are given in Table 4.

Table 4. Results of Paired-samples t-test of Experimental Group in Pre and Posttest

\begin{tabular}{|c|c|c|c|c|c|c|c|c|}
\hline & \multicolumn{5}{|c|}{ Paired Differences } & \multirow[b]{3}{*}{$\mathrm{t}$} & \multirow[b]{3}{*}{$\mathrm{df}$} & \multirow[b]{3}{*}{ Sig. (2-tailed) } \\
\hline & \multirow[b]{2}{*}{ Mean } & \multirow[b]{2}{*}{ Std. Deviation } & \multirow[b]{2}{*}{ Std. Error Mean } & \multicolumn{2}{|c|}{$\begin{array}{l}95 \% \text { Confidence } \\
\text { Interval of the } \\
\text { Difference }\end{array}$} & & & \\
\hline & & & & Lower & Upper & & & \\
\hline $\begin{array}{l}\text { Pair } 1 \text { Exp. pretest } \\
\text { Exp. Posttest }\end{array}$ & -1.53750 & 17.56 & 2.77 & -20.99 & -9.75 & -5.536 & 39 & .000 \\
\hline
\end{tabular}

The significance level in Table 4 is .000 which is smaller than the identified level of significance $.05(.000<.05)$. This shows the difference between the performance of the experimental group in pretest and posttest is statistically significant. This rejects the first null hypothesis of the research. Differently stated, when tenets of genre based approach are planted in reading classes, this leads to more desirable outcomes.

\subsection{Addressing Second Research Hypothesis}

In the posttest scores, the experimental and control group's mean scores were compared. The results are presented in the following section.

Table 5. Descriptive Statistics of the Reading Posttest of Experimental and Control Groups

\begin{tabular}{llllll}
\hline & Groups & $\mathrm{N}$ & Mean & Std. Deviation & Std. Error Mean \\
\hline posttest & Exp. & 40 & 67.5000 & 16.06397 & 2.53994 \\
\cline { 2 - 6 } & Ctl. & 40 & 60.4250 & 11.76018 & 1.85945 \\
\hline
\end{tabular}

According to Table 5, in the posttest, the mean score of the participants in the experimental group is 67.50 and in the control group is 60.42 , showing a mean difference of 7.08 which seems to be significant. Figure 2 compares the performance of the participants in the posttest. 


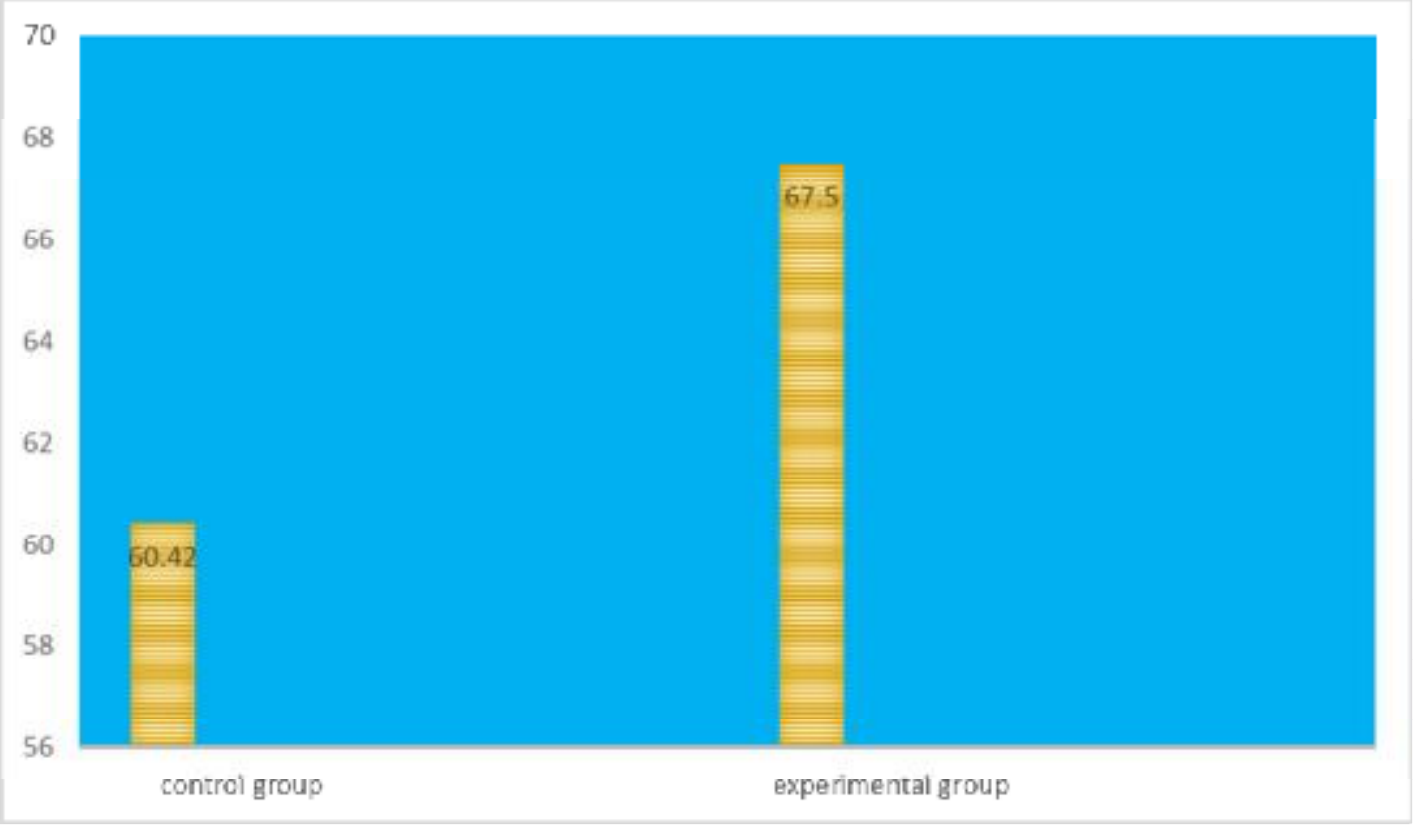

Figure 2. Mean Difference between the Performance of the Experimental and Control Groups

Table 6. Results of the Independent-samples t-test of the Posttest Scores of Two Groups

\begin{tabular}{|c|c|c|c|c|c|c|c|c|}
\hline & \multicolumn{2}{|c|}{$\begin{array}{c}\text { Levene's Test for } \\
\text { Equality of } \\
\text { Variances }\end{array}$} & \multicolumn{6}{|c|}{ t-test for Equality of Means } \\
\hline & \multirow[t]{2}{*}{$\mathrm{F}$} & \multirow[t]{2}{*}{ Sig. } & \multirow[t]{2}{*}{ df } & \multirow[t]{2}{*}{$\begin{array}{l}\text { Sig. (2- } \\
\text { tailed) }\end{array}$} & \multirow[t]{2}{*}{$\begin{array}{c}\text { Mean } \\
\text { Difference }\end{array}$} & \multirow[t]{2}{*}{$\begin{array}{l}\text { Std. Error } \\
\text { Difference }\end{array}$} & \multicolumn{2}{|c|}{$\begin{array}{c}95 \% \text { Confidence } \\
\text { Interval of the } \\
\text { Difference }\end{array}$} \\
\hline & & & & & & & Lower & Upper \\
\hline $\begin{array}{l}\text { posttest Equal } \\
\text { variances } \\
\text { assumed }\end{array}$ & .910 & .343 & 2.24878 & .027 & 7.07500 & 3.14783 & .80815 & 13.34185 \\
\hline $\begin{array}{l}\text { Equal } \\
\text { variances not } \\
\text { assumed }\end{array}$ & & & 2.24871 .476 & .028 & 7.07500 & 3.14783 & .79913 & 13.35087 \\
\hline
\end{tabular}

According to the results in Table 6, the identified level of significance is smaller than the observed level of significance which is $.000(.05>.000)$; therefore, it can be understood that using genre-based approach has a great influence on the performance of EFL learners in reading classes. Also it can be claimed that genre-based approach to reading leads to a significant difference between the performance of the control and experimental groups in reading posttest.

\section{Discussion and Conclusion}

According to the data gained from this study and the statistics presented in the previous section, it is completely clear that using such strategies as genre-based can be influential in comparison to conventional methods of teaching reading. In fact, the observed difference between experimental and control group posttest scores was significant. Therefore, based on these findings, the first hypothesis of the study was rejected, and we can answer the first question and say that genre-based teaching methodology can enhance Iranian EFL learners' reading performance. The findings were also the bases to reject the second hypothesis and answer the second question in this way that there is a significant difference between reading comprehension skills of EFL learners' instructed by genre-based language methodology in reading pre and posttests. Thus, given its many benefits and advantages, an integration of genre based teaching instruction is considered among the best methods of instructing reading to EFL learners.

During the last twenty years, reading has attracted much attention. Generally, reading has been considered as the most necessary skill in students' higher level of education (Jordan, 1997), and this is true of Iranian students. Flowerdew and Swales (as cited in Hyon, 1996) primarily outlined the genre approach with focus on the formal distinctiveness of genres in order to help students gain understanding of the communicative purposes and linguistic features of texts that they are required to write in their professional discourses, while these experts paid less attention to the specific roles of content and their social environments (p. 695). They regarded genres as devices for examining and teaching the written texts that students needed to master in specific settings. Therefore, an assigned genre seems to serve as an influential 
tool for both the learning and teaching of reading for both students and teachers. Furthermore, the genre approach encourages students to participate in the world around them, to comprehend reading as a tool that they can utilize, and to realize how readers manage content to promote logical organization. It also allows students to become more flexible in their thinking and eventually to realize how authors organize their reading comprehension. These debates shed more light on the significance of reading skills. Thus, it is hoped that the present study resolves some of the above-mentioned controversies related to reading comprehension of EFL learners.

In so far as the question of the study is concerned, the results of an independent-samples t-test showed that there was a significant difference between the performance of the participants of the experimental group and the control group in terms of reading comprehension, when genre-based was applied to teach reading. The reason can be found in the advantages presented by Hayland (2004) who believes that genre-based instruction clarifies to learn in order to facilitate the acquisition of reading comprehension. Furthermore, Hayland (2004) believes that a coherent framework for focusing on both language and contexts is provided by this approach. In addition, genre-based guarantees specific course objectives and content. Another reason for that may be due to the fact that genre-based provides a central role for the teacher as motivator of student learning and creativity, and this approach makes patterns and possibilities of variation in valued texts available.

The noted discussion investigates the influence of genre-based teaching reading from different dimensions. Briefly, if we consider doing something with the information as the goal of reading a text, the results of the present study showed that genre-based teaching reading has a significant and positive influence on improving EFL learners reading comprehension ability.

The findings of the present research are in accordance with the study done by Haria and Midgette (2014) who made an investigation to examine the effect of genre-based instruction on reading comprehension strategy of the students. The results of their study revealed improvement on the students' proficiency in terms of identifying argumentative elements and summarizing arguments.

In addition, the results of this study confirm the study by Rozimela (2014) who illustrated a significant relationship between genre awareness and reading comprehension of EFL students. Furthermore, the results of his study showed that the students with higher genre awareness significantly outperformed on reading comprehension.

In addition, this study is in line with the study by Sadeghi, TaghiHassani and Hemmati (2013) who investigated the influence of genre-based instruction on ESP learners' reading comprehension. The results of the reading comprehension test, analyzed by a t-test and independent-samples t-test showed that genre-based teaching significantly enhance EFL learners' reading comprehension ability. The descriptive and inferential statistics showed that learners' reading comprehension improved significantly compared to non-genre-group.

Finally, the results of this study support the results of Shabani Minaabad and Fallahe Khoshkholgh's (2012) research in which they scrutinized the influence of genre-based pedagogy on ESP leaners' reading comprehension and the relationship between their reading comprehension achievement and their general English proficiency. The study shows that genre-based pedagogy significantly affects ESP learners' reading comprehension.

On the other hand, some advocators have shown that the genre approach is more appropriate for learners at the beginning or intermediate proficiency levels in a second language rather than those at advanced levels; it releases students from deep anxieties of their reading tasks. When learning something new, people usually want to find some cases considered as samples. It is clear that reading tasks can be more demanding than other language skills, so students at low proficiency level absolutely need something to rely on because of little exposure to English reading.

In addition, the findings of this study are against some ideas, for instance it is said that despite genres' beneficial roles, there are two demerits about the genre approach. One is that it neglects the skills required to produce content, and the other concern is that it ignores learners' self-sufficiency (Byram, 2004). Finally, Bawarshi (2000) stated that, "at its best, genre-based approach helps learners to identify and interpret literary texts, while at its worst; it interferes with the learners' creativity" (p. 343).

In fact, this study was an attempt to investigate reading comprehension and see whether genre-based teaching techniques enhance Iranian EFL learners' reading comprehension. The statistical analyses of this experiment showed that the idea of effectiveness of genre-based instruction on the reading ability was proved right. The language teachers can make use of genre-based instruction in their classes and train students what genre-based instruction is. Therefore, teachers must help students to be more aware of their own learning.

\section{Pedagogical Implications}

At first, it should be mentioned that the findings of this study could enrich the literature in the area of foreign language learning especially teaching reading to Iranian EFL learners. Moreover, the finding of the study can be used by language practitioners and curriculum developer to consider students' need of genres in the process of need analysis. For choosing the instructional material again those which are more genre-based can be used to have a better educational context in which EFL learners' reading comprehension can be developed. Finally, teachers as the most important stakeholders can benefit from the results of the present study to improve the EFL learners' reading comprehension. The present study and studies like this which support the idea of effectiveness of genre-based instruction on developing reading can help teacher trainers, English teachers, course book writers and curriculum designers to be more aware of 
the benefits of genre-based instruction and to incorporate the tenets of genre-based into their lessons, course books and curricula to help learners be aware of the positive and influential features of reading classes.

\section{Limitations of the Study}

It is worth mentioning that this study does not intend to generalize its results about the positive influence of task based teaching reading because there are several limitations that should be removed. The first limitation is the time of instruction. A lot of literature emphasizes that teaching reading comprehension is a long-term program. However, the present study was conducted for 12 sessions including the test sessions. It is recommended that the instruction should last at least for a term up to one academic year. Second, the study was restricted to EFL learners of just one university in Iran. Third, the participants in this research were limited to 80 EFL learners. Fourth, the number of passages used in the reading classes in this research was limited to limited books and passages.

\section{Recommendations for Future Research}

For the completion of the results of the present study, the topic needs to be explored more in some other studies. With regard to the present study, further research may be necessary in the following areas: The main concern of the present study was to investigate the influence of genre-based instruction on Iranian EFL learners' reading ability. Similar researches can be administered on other language skills such as speaking, writing, and listening comprehension of Iranian EFL learners. The subjects in the present study were female EFL learners. If the same study can be conducted on co-educational classes, the results may be different. This study made use of experimental design; therefore, other designs may be used to further our understanding of the concept under question. EFL students of different majors may act differently in reading classes using this strategy. Regarding the materials used in this study, different kinds of texts can be explored to see if the same results will be gained.

\section{References}

Bawarshi, A. (2000). The genre function. College English, 62(3), 335-360.

Bhatia, V. K., (1993).Analyzing Genre: Language Use in Professional Settings, London: Longman.

Byram, M. (2004). Genre and genre-based teaching. The Routledge.

Halliday, M.A.K. (1978). Language as Social Semiotic. London: Edward Arnold.

Hayland, K. (2004). Genre and Second Language Writing. Ann Arbor: The university of Michigan Press.

Hammond, J., \&Derewianka, B. (2001). Genre. In Carter and Nunan (Eds.). The Cambridgecguide to teaching English to speakers of other languages. Cambridge: Cambridge University Press.

Hyland, K. (2007). Genre pedagogy: Language, literacy and L2 writing instruction. Journal of Second Language Writing. 5(2), 56-64.

Hyon, U. K. L (1996). A Genre in three traditions: Implications for ESL. TESOL Quarterly, 30(4), 693-717.

Khatibi, M.B. (2014). The Effect of Genre-Based Teaching on EFL Learners' Speaking Performance. IJRELT, 1(3), 3852

Martin, J. R., (1993) A Contextual Theory of Language. In The Powers of Literacy: A Genre Approach to Teaching Writing .Pittsburgh: University of Pittsburgh Press.

Miller, C. R. (1984). Genre as social action [Electronic version]. Quarterly Journal of Speech, 70, 151-167.

Osman, H. (2004). Genre-based instruction for ESP. Retrieved from http://www.melta.org.my/ ET//2015-13.pdf

Rozimela, Y. (2014). The Students' Genre Awareness and their reading comprehension of different text types. International Journal of Asian Social Science, 4(4), 460-469.

Sadeghi, B., TaghiHassani, M., \& Hemmati, M. R. (2013). The Effects of Genre-based Instruction on ESP Learners' Reading Comprehension. Theory and Practice in Language Studies, 3(6), 1009-1020

Shabani M., M. \&Fallahe K, F. (2012). Investigating the Effect of Genre-Based Pedagogy on English for Specific Purpose Learners' Reading Comprehension. World Applied Sciences Journal 18 (2), 251-260.

Shishehsaz, A. R. (2006). The Effect of Explicit Genre Teaching on EST students' Reading comprehension. Unpublished MA Thesis. Islamic Azad University, Science and Technology, Tehran, Iran.

Swales, J. M. (1990). Genre analysis. Cambridge: Cambridge University Press.

Swami, J. A. (2008). Sensitizing ESL learners to genre. TESL-EJ, 2 (3), 23-41. Genres of writing. Michigan: Michigan University Press.

Vygotsky. L. (1978). Mind in Society. Cambridge MA: Harvard University Press. 